\title{
Etiological agents of wounds infection and their antibiogram against various antibiotics in patients of Gilgit-Pakistan
}

\author{
Sughra Yaqub ${ }^{1}$, Khalil Ahmed ${ }^{1}$, Maisoor Ahmed Nafees ${ }^{1}$, Saif-Ud- \\ Din $^{2 *}$, Raja Imran ${ }^{1}$, Ijad Hussain ${ }^{3}$ and Nazia Shuja ${ }^{1}$ \\ .1. Department of Biological Sciences, Karakoram International University, Gilgit-Baltistan-Pakistan \\ 2. Department of Environmental Sciences, Karakoram International University, Gilgit-Baltistan-Pakistan \\ 3. Pathology laboratory District Headquarter Hospital (DHQ) Gilgit-Baltistan-Pakistan \\ *Corresponding author's email: gltsaifuddin@gmail.com
}

Citation

Sughra Yaqub, Khalil Ahmed, Maisoor Ahmed Nafees, Saif-Ud-Din, Raja Imran, Ijad Hussain andNazia Shuja. Etiological agents of wounds infection and their antibiogram against various antibiotics in patients of GilgitPakistan. Pure and Applied Biology. Vol. 7, Issue 2, pp736-744. http://dx.doi.org/10.19045/bspab.2018.70092

\begin{tabular}{llll}
\hline \hline Received: 07/03/2018 & Revised: 11/06/2018 & Accepted: 22/06/2018 & Online First: 26/06/2018 \\
\hline \hline
\end{tabular}

\section{Abstract}

Wound infections are one of the most common infection in which bacterial flora proliferates and delayed the wound healing process. Normally skin normal flora and environment contaminate the wounds. This study was conducted in Gilgit and primary aim of the study was to determine the common causative agents of wound infection and their fluctuating susceptibility pattern against commonly used antibiotics. In this study 185 infected wound samples were taken from patients with high suspicion of wound infection attended at inpatient and outpatient departments of district headquarter (DHQ) hospital Gilgit from December 2014 to September 2015. Swabs from, infected wounds were taken aseptically by using Levine's technique and cultured on blood and MacConkey agars. Bacterial colonies were Gram stained and examined microscopically. Biochemical tests were done to identify pathogens. The antibiotic sensitivity test was performed by disk diffusion method. Both the genders were included in this study and age of patients in the study was ranged from 6 months to 75years. Out of 185 wound swabs, 124 samples yielded significant bacterial growth, the prevalence of wound infection was $67.02 \%$. S. aureus as most prevalent pathogen 59 (39.3\%) followed by Pseudomonas aeruginosa 31(20.67\%). Age group and sex did not affect the prevalence. Most prevalent wound type was trauma 70 (66.67\%). All Gram positive cocci were susceptible to vancomycin and linezolid (83.33-100\%). All Gram negative bacilli showed good response towards piperacillin-tazobactum and imipenem in a range of 90-100\%. This study revealed the alarming increase of wound infections by drug resistant bacterial pathogens.

Keywords: Antibiotic resistance; Antibiotic sensitivity; Causative agents; infected wounds

\section{Introduction}

For a long time wound, infections have been a common problem in the field of medicine. Even Progresses in control of infections have eliminated this issue because of development of drug resistance. Wounds may be due to accidents, pathologic agents or postoperative Pondai et al [1]. Following a wound, there is exposure of subcutaneous tissue, which leads to the development of a favorable nutritious, moist, warm environment for the multiplication and 
colonization of microorganisms. Therefore, any wound is at risk of becoming infected. The other major risk factors for wound infection may include old age, prolonged stay in hospital, immune-compromised patients and infected devices Prabha et al [2]. Wound may be infected by a single or multiple organisms. Many of wound infections are caused by the pathogens that are endogenous flora of the patient's skin, mucous membranes or hollow viscera Mangram et al [3]. Most of the wound infections are caused by nosocomial pathogens, which may differ country to country, and even from one hospital to another in same region Mulu et al. [4]. Most commonly isolated pathogens of wound are Pseudomona species, Staphylococcus aureus, Klebsiella species, Escherichia coli, Streptococcus species, Enterobacter species and coagulase negative Staphylococci Akingbade et al [5].

In developing countries wound infection are still important causes of morbidity and mortality. The studies done on wound infections, the regional and local variations have been seen in terms of their causative pathogens and their sensitivity. This means that physicians need to identify the prevalent pathogen and its resistance patterns in particular localities Pondai et al [1]. Appropriate treatment of wound infection involves treating the right bacteria with right antimicrobial administered in the right manner for right length of the time to prevent the emergence of resistant organisms Micheal et al [6].

The United State of America, Center for Disease Control (CDC), the World Health Organization (WHO) and many other researchers have documented the increasing rate of infection by Multidrug Resistance bacteria, new antibiotic resistant pathogens are emerging in clinical environment Davies et al [7]. These bacteria pose a greater challenge in the treatment of infections, which often leads to the prolonged illness, amputation, and even risk of death. Hence, it is necessary to have knowledge about the etiological agents and their antimicrobial susceptibility in particular regions, it will be beneficial for the selection of empirical antimicrobial therapy.

\section{Materials and methods}

The specimens were taken from patients with infected wounds of any type including trauma (traffic road accidents, osteomyelitis etc.), post-operative wound infection, and abscess and burn wound infections.

All swabs obtained, by using Levine's technique, were cultured directly on blood and MacConkey agar for isolation of aerobic bacteria Levine et al [8]. Cultured plates were examined after overnight incubation at $37^{\circ} \mathrm{C}$. Identification of pathogenic bacteria was based on gram stained smear, colony morphology, biochemical test and culture media.

Antibiotics sensitivity was carried out by disk diffusion method Bauer et al [9] and Ahmed et al [10]. One $\mathrm{ml}$ of each identified bacterial isolate was prepared from an overnight culture and adjusted to 0.5 McFarland Standard. A sterilized wooden swab was soaked in inoculums used to streak on Mueller-Hinton agar (MHA) plates and allowed to dry at room temperature. Commercially available sterile disks of antibiotics, Ampicillin $(10 \quad \mu \mathrm{g})$, Amoxicillin/Clavulanic acid (AMP/Cl- 30 $\mu \mathrm{g})$, Ciprofloxacin $(5 \mu \mathrm{g})$, Chloramphenicol (C $30 \mu \mathrm{g}$ ) Gentamycin (GM- $10 \mu \mathrm{g}$ ), Linezolid (Le-30 $\mu \mathrm{g}$ ), Vancomycin (V-

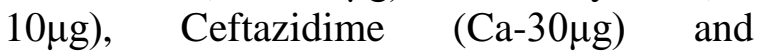
Erythromycin $(\mathrm{E}-10 \mu \mathrm{g})$ for Gram positive and Amoxicillin/Clavulanic acid (AMP/Cl$30 \mu \mathrm{g})$, Ciprofloxacin $(5 \mu \mathrm{g})$, Chloramphenicol (C $30 \mu \mathrm{g}$ ) Gentamycin

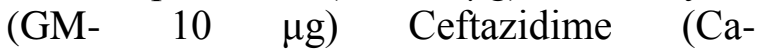
30 $\mu \mathrm{g})$,Piperacillin- Tazobactum (Pt $100 / 10 \mu \mathrm{g}$ ) and Imipenem (Imp-10 $\mathrm{g}$ ) for Gram negative were placed aseptically on the pre streaked agar plates with sterilized 
forceps and then incubated at $37^{\circ} \mathrm{C}$ for $18-24$ hrs. E. coli ATCC 25922, sensitive to all these drugs, was used as a control and the sensitivity of the antibiotics was recorded by measuring the zone of inhibition around the discs for each of the isolated cultures in millimeters $(\mathrm{mm})$. The interpretation of the measurement for sensitive and resistant bacteria was made according to the manufacturer's standard zone size CLSI [11].

Statistical analysis

Differences in antibiotic resistance between wound types and between sexes and age groups were analyzed using Pearson Chi Square test. A difference of $\mathrm{p}<0.05$ was considered significant.

\section{Results}

\section{Prevalence of wound infection}

During the whole study 185 wound samples were investigated at microbiology department in pathology laboratory (Table 1) at district headquarter hospital Gilgit. There were total 123 male and 62 female subjects. Ages ranged from 6 months to $>75$ years. The swabs obtained from males were relatively high infected as compare to female and highest cases of wound infections were among the age group of 21-30 years $(70.96 \%)$. There was greater incidence of wound infection in the age group of 21 to 30 years but there was no significant association between age and the incidence of wound infection $(\mathrm{p}=0.648)$. In male the infestation was $83(67.48 \%)$ which was slightly higher than female 41. (66.12\%). But statistically there was no significant association between the incidence of wound infection and the sex of the subject $(\mathrm{p}=0.490)$ or between the type of wound and the sex of the subject $(\mathrm{p}=$ 0.186 ).

A total of 124 samples (Figure 1) had significant bacterial growth revealing wound infection, while 61 samples did not show any significant growth. 101 wounds were infected with a mono organism. However 20 wounds were infected with a couple of bacteria, while three organisms were isolated from 3 specimens. A total of 150 bacteria were isolated.

The prevalence of different pathogenic bacteria isolated from infected wounds (Table 2). Staphylococcus aureus (39.3\%) was the most predominant isolate followed by Pseudomonas aeruginosa (20.67\%), Escherichia Coli24 (16.02\%). Coagulase negative Staphylococci and Proteus species 12(8.0\%) each Klebsiella spp. 10(6.67\%) and Streptococcusspp. 02 (1.3\%). The number of Gram-negative bacteria were higher 77 (51.33\%) than Gram Positive 73 (48.67\%).

Table 1. Age and gender wise distribution of infected wound patients

\begin{tabular}{|c|c|c|c|c|}
\hline \multirow{2}{*}{$\begin{array}{c}\text { Age } \\
\text { groups } \\
\text { (years) }\end{array}$} & $\begin{array}{c}|c| \\
\text { No. of Investigated } \\
\text { samples (\%) }\end{array}$ & $\begin{array}{c}\text { No. of } \\
\text { Infected } \\
\text { samples (\%) }\end{array}$ & Male (\%) N=123 & $\begin{array}{c}\text { Female } \\
(\%) \text { N=62 }\end{array}$ \\
\cline { 2 - 5 } & $5(2.7)$ & $3(60.0)$ & $02(2.41)$ & $01(2.44)$ \\
\hline $0-10$ & $24(13.0)$ & $15(62.5)$ & $11(13.55)$ & $04(9.76)$ \\
\hline $20-$ Nov & $62(33.5)$ & $44(70.96)$ & $32(38.55)$ & $10(24.39)$ \\
\hline $21-30$ & $36(19.5)$ & $24(66.6)$ & $13(15.66)$ & $11(26.83)$ \\
\hline $31-40$ & $30(16.2)$ & $21(70.0)$ & $13(15.66)$ & $08(19.51)$ \\
\hline $41-50$ & $14(7.6)$ & $9(64.28)$ & $6(7.23)$ & $03(7.32)$ \\
\hline $51-60$ & $10(5.4)$ & $6(60.0)$ & $4(4.82)$ & $3(7.32)$ \\
\hline $61-70$ & $4(2.2)$ & $2(50.0)$ & $2(2.41)$ & $1(2.44)$ \\
\hline$>70$ & $185(100.0)$ & $124(67.02)$ & $83(67.48)$ & $41(66.12)$ \\
\hline Total & &
\end{tabular}




\section{No. of Isolates}

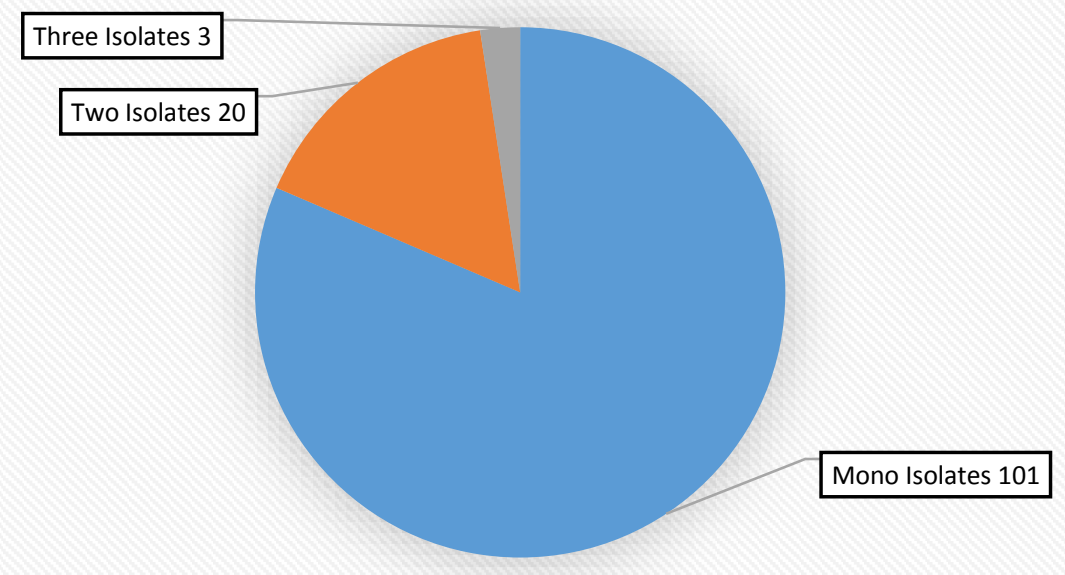

Figure 1. Number of bacteria isolated showing significant bacterial growth revealing wound infection

Table 2. Prevalence of pathogenic bacteria isolated from infected wounds patients reported at DHQ hospital Gilgit

\begin{tabular}{|c|c|}
\hline Isolated Bacterial Pathogens & No. of Isolates (\%) \\
\hline \multicolumn{1}{|c|}{ Gram Positive } \\
\hline Staphylococcus aureus & $59(39.3 \%)$ \\
\hline Coagulase-negative Staphylococcus spp. & $12(8.0 \%)$ \\
\hline Streptococcus spp. & $02(1.3 \%)$ \\
\hline Total & $\mathbf{7 3 ( 4 8 . 6 7 \% )}$ \\
\hline \multicolumn{2}{|c|}{ Gram negative } \\
\hline Pseudomonas aeruginosa & $31(20.67 \%)$ \\
\hline Escherichia coli & $24(16.02 \%)$ \\
\hline Klebsiella spp. & $10(6.67 \%)$ \\
\hline Proteus spp. & $12(8.0 \%)$ \\
\hline Total & $\mathbf{7 7 ( 5 1 . 3 3 \% )}$ \\
\hline G. Total & $\mathbf{1 5 0}$ \\
\hline
\end{tabular}

The frequencies of various wound types and their infestation level was drawn (Table 3). Wound was categorized into four types. Most prevalent type of wound was trauma 105 $(56 \%)$ and infestation was found $70(66.67 \%)$ followed by surgical wound infection $35(18.9 \%)$ with infestation rate of 26(74.28\%), burn $25(13.5 \%)$ and infestation was $18(72.0 \%)$ and lowest $20(10.8 \%)$ cases of abscess were reported with infestation rate of $10(50 \%)$. High infestation was observed in surgical wound 26 (74.28) and lowest was observed in abscess 10 (50.0).

Frequency of pathogenic bacteria isolated according to various wound types has been mentioned in (Table 4). The highest Prevalence of pathogenic bacteria 82 $(54.67 \%)$ was in trauma patients followed by surgical wounds34 (22.67\%), burn 21(14\%) and low number of pathogens were isolated from abscess 13 (8.67\%). Among the Gram positive bacteria the highly isolated bacteria 
was Staphylococcus aureus 59 (39.3\%) most frequently isolated from trauma patients 37 (62.7\% followed by surgical $10(16.9 \%)$, burn $7(11.86 \%)$ and Abscess 5 (8.47\%). The Staphylococcus spp. Infestation was $12(8 \%)$ and its highest infestation was also found in trauma $7(58.33 \%)$ followed by surgical 3 (25\%), burn and abscess $1(8.33 \%)$ each. Streptococcus spp infestation was $2(1.3 \%)$ and was isolated only from trauma patients. Among the Gram negative bacteria the Pseudomonas aeruginosa was 31 (20.67\%) and very highly isolated from trauma patients $14(45.16 \%)$ followed by surgical 11 $(35.48 \%)$, abscess $4(12.9 \%)$ and in burn 2
$(6.45 \%)$. The total infestation of $E$. coli in various types of wound was 24 (16.02\%) and it was most frequently isolated in trauma 11 (45.8\%) followed by surgical 7 (29.1\%, burn $4(16.67 \%$, abscess $2(8.33 \%)$. The overall infestation of Klebsiella Spp. was 10 (6.67\%) and more frequently isolated from trauma patients $6(60 \%)$ followed by surgical and burn patients $2(8.33 \%)$ each. There was no infestation of Klebsiella Spp in abscess. Proteus infestation was $12(8 \%)$ and was highest in trauma and burns patients 5 $(41.67 \%)$ each followed by surgical and abscess $1(8.33 \%)$.

Table 3. Frequency of wound type

\begin{tabular}{|c|c|c|}
\hline Wound type & Frequency (\%) & No. of infected samples (\%) \\
\hline Trauma & $105(56)$ & $70(66.67)$ \\
\hline Surgical & $35(18.9)$ & $26(74.28)$ \\
\hline Burn & $25(13.5)$ & $18(72.0)$ \\
\hline Abscess & $20(10.8)$ & $10(50.0)$ \\
\hline Total & $\mathbf{1 8 5}(\mathbf{1 0 0})$ & $\mathbf{1 2 4}(\mathbf{6 7 . 0 2})$ \\
\hline
\end{tabular}

Table 4. Frequency of pathogenic bacteria according to wound types

\begin{tabular}{|c|c|c|c|c|c|}
\hline $\begin{array}{c}\text { Isolated Bacterial } \\
\text { Pathogens }\end{array}$ & $\begin{array}{c}\text { Trauma } \\
(\boldsymbol{\%})\end{array}$ & Surgical $(\boldsymbol{\%})$ & $\begin{array}{c}\text { Burn } \\
(\boldsymbol{\%})\end{array}$ & $\begin{array}{c}\text { Abscess } \\
(\boldsymbol{\%})\end{array}$ & $\begin{array}{c}\text { Total } \\
(\boldsymbol{\%})\end{array}$ \\
\hline Staphylococcus aureus & $37(62.7)$ & $10(16.9)$ & $\begin{array}{c}07 \\
(11.86)\end{array}$ & $05(8.47)$ & $59(39.3)$ \\
\hline $\begin{array}{c}\text { Coagulase-negative } \\
\text { Staphylococcus spp. }\end{array}$ & $07(58.33)$ & $03(25)$ & $01(8.33)$ & $01(8.33)$ & $12(8.0)$ \\
\hline Streptococcus spp. & $02(100)$ & $00(0)$ & $00(0)$ & $00(0)$ & $02(1.3)$ \\
\hline Pseudomonas aeruginosa & $14(45.16)$ & $11(35.48)$ & $02(6.45)$ & $04(12.9)$ & $\begin{array}{c}31 \\
(20.67)\end{array}$ \\
\hline Escherichia coli & $11(45.8)$ & $07(29.1)$ & $\begin{array}{c}04 \\
(16.67)\end{array}$ & $02(8.33)$ & $\begin{array}{c}24 \\
(16.02)\end{array}$ \\
\hline Klebsiella spp. & $06(60)$ & $02(20)$ & $02(20)$ & $00(0)$ & $10(6.67)$ \\
\hline Proteus spp. & $05(41.67)$ & $01(8.33)$ & $\begin{array}{c}05 \\
(41.67)\end{array}$ & $01(8.33)$ & $12(8)$ \\
\hline Total & $82(54.67)$ & $34(22.67)$ & $21(14)$ & $13(8.67)$ & $150(100)$ \\
\hline
\end{tabular}

As per Antibiotic susceptibility of gram positive cocci (Table 5), S. aureus was 59 $(100 \%)$ sensitive against Linezolid followed by Vancomycin 58 (98.30\%), Ciprofloxacin 30 (50.84\%), Ceftazidime 28 (47.45\%), Gentamycin 24 (40.67\%), Erythromycin 18 
(30.50\%), Chloramphenicol 13 (22.03\%), Amoxycillin/Clavulanic acid 11 (18.64\% and Ampicillin 3 (5.08\%). Staphylococcus sensitivity against Linezolid was $12(100 \%)$ followed by Vancomycin 10 (83.33\%), Ciprofloxacin 7 (58.33\%), Ceftazidime and Gentamycin 6 (50\%) each, Chloramphenicol
3 (25\%), Amoxicillin/Clavulanic acid and Erythromycin 2 (16.66\%). Streptococci spp. sensitive against Linezolid and Vancomycin was $2(100 \%)$ each followed by Chloramphenical and Ceftazidime1 (50\%) each.

Table 5. Antibiotic susceptibility pattern of gram positive cocci (\% sensitivity)

\begin{tabular}{|c|c|c|c|}
\hline Name of antibiotic discs & $\begin{array}{l}\text { Staphylococcus } \\
\text { aureus } N=59\end{array}$ & $\begin{array}{c}\text { Staphylococcus spp. } \\
N=12\end{array}$ & $\begin{array}{c}\text { Streptococcus spp. } \\
N=02\end{array}$ \\
\hline Gentamycin (GM- $10 \mu \mathrm{g})$ & $24(40.67)$ & $06(50.0)$ & 0 \\
\hline Erythromycin $(\mathrm{E}-15 \mu \mathrm{g})$ & $18(30.50)$ & $02(16.66)$ & 0 \\
\hline Ciprofloxacin (Cip -5 $\mu \mathrm{g})$ & $30(50.84)$ & $07(58.33)$ & 0 \\
\hline $\begin{array}{c}\text { Chloramphenicol (C-30 } \\
\mu \mathrm{g})\end{array}$ & $13(22.03)$ & $03(25.0)$ & $01(50.0)$ \\
\hline $\begin{array}{l}\text { Amoxycillin/Clavulanic } \\
\text { acid (AMP/Cl- } 30 \mu \mathrm{g})\end{array}$ & $11(18.64)$ & $02(16.66)$ & 0 \\
\hline Ampicillin (AMP- $10 \mu \mathrm{g}$ ) & $03(5.08)$ & $01(8.33)$ & 0 \\
\hline Linezolid $(\mathrm{Le}-30 \mu \mathrm{g})$ & $59(100)$ & $12(100)$ & $02(100)$ \\
\hline Vancomycin $(\mathrm{V}-10 \mu \mathrm{g})$ & $58(98.30)$ & $10(83.33)$ & $02(100)$ \\
\hline Ceftazidime $(\mathrm{Ca}-30 \mu \mathrm{g})$ & $28(47.45)$ & $06(50.0)$ & $01(50.0)$ \\
\hline
\end{tabular}

Antibiotic susceptibility of gram negative rods (Table 6), P. aeruginosa were sensitive against Imipenem and Piperacillin/Tazobactum 31 (100\%) followed by Ciprofloxacin 17 (54.83\%), Ceftazidime 16 (51.61\%), Amoxycillin/Clavulanic acid 5 (16.12\%), Gentamycin and Chloramphenicol $4(12.90 \%)$ each. E. Coli sensitivity against Imipenem was $24(100 \%)$, followed by Piperacillin- Tazobactum 23 (95.83\%), Ciprofloxacin 8 (33.33\%), Chloramphenicol 6 (25\%), Ceftazidime 5 (20.83\%), Amoxycillin/Clavulanic acid 3 (12.5\%) and Gentamycin 2 (8.33\%). Klebsiella sensitivity was against Imipenem $10(100 \%)$ followed by Piperacillin- Tazobactum 9 (90\%), Ciprofloxacin 4 (40\%), Chloramphenicol 2 (20\%), Gentamycin and Ceftazidime $1(10 \%)$ each.

\section{Discussion}

In this study 185 infected wound samples were processed to determine the common causative agents of wound infection and their fluctuating susceptibility pattern against commonly used antibiotics in Gilgit.

The study revealed that the prevalence of wound infection among males were high than females. These findings are consistence with Nazeer et al. [12] but this difference has no significance as Egbe et al. [13] and Taiwo et al. [14] also reported the same findings in their studies conducted in Nigeria and Africa. Current study reflects wound infection was more prevalent in the age group of 21-30 years $62(33.5 \%)$ followed by 31-41 years age group $36(19.5 \%)$ and $41-50$ years age group $30(16.2 \%)$. Which was in contrast with study conducted in Nepal and India, the prevalence was high in age group 41-50 Nazeer et al. [12] and Bhatt et al. [15]. However, our findings go inconsistent with the results of study conducted by Pondai $e t$ al. [1] in Nigeria and a study from Ethiopia Mulugeta et al. [16]. Present study depicts 
that the prevalence of wound infection was $67.02 \%$, this figure is in agreement with study conducted in India (69\%) and Nepal (62\%) by Nazeer et al. [12] and Bhatt et al. [15]. However, these findings differ with the study conducted by Pondai et al. [1] and Sultana et al. [17] where the prevalence was high $86.2 \%$ and $83.65 \%$ respectively.
The results of the current study illustrates the high prevalence of Gram negative bacteria in wound infection, whereas same pattern of prevalence was reported by Kehinde et al. [18] who documented that the rate of Gram negative bacterial isolates were double than Gram positive isolates in burnt wound infections.

Table 6. Antibiotic susceptibility pattern of Gram-negative rods (\% sensitivity)

\begin{tabular}{|c|c|c|c|c|}
\hline Name of antibiotic discs & $\begin{array}{c}\text { Pseudomonas } \\
\text { aeruginosa } N=31\end{array}$ & $\begin{array}{l}\text { E. coli } \\
N=24\end{array}$ & $\begin{array}{c}\text { Proteus } \\
\text { Spp. } N=12\end{array}$ & $\begin{array}{l}\text { Klebsiella } \\
\text { Spp. } N=10\end{array}$ \\
\hline 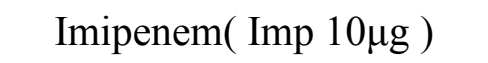 & $31(100)$ & $24(100)$ & $12(100)$ & $10(100)$ \\
\hline Gentamycin (GM- $10 \mu \mathrm{g})$ & $04(12.90)$ & $02(8.33)$ & $02(16.66)$ & $01(10.00)$ \\
\hline Ciprofloxacin (Cip -5 $\mu \mathrm{g})$ & $17(54.83)$ & $08(33.33)$ & $05(41.66)$ & $04(40.00)$ \\
\hline $\begin{array}{l}\text { Amoxycillin/Clavulanic } \\
\text { acid (AMP/Cl- } 30 \mu \mathrm{g})\end{array}$ & $05(16.12)$ & $03(12.5)$ & $02(16.66)$ & $00(0)$ \\
\hline $\begin{array}{l}\text { Piperacillin- Tazobactum } \\
(\mathrm{Pt} 100 / 10 \mu \mathrm{g})\end{array}$ & $31(100)$ & $23(95.83)$ & $31(100)$ & $09(90.00)$ \\
\hline Chloramphenicol $(\mathrm{C}-30 \mu \mathrm{g})$ & $04(12.90)$ & $06(25.00)$ & $04(33.33)$ & $02(20.00)$ \\
\hline Ceftazidime $(\mathrm{Ca}-30 \mu \mathrm{g})$ & $16(51.61)$ & $05(20.83)$ & $03(25.00)$ & $01(10.00)$ \\
\hline
\end{tabular}

The most common pathogens isolated in present study was $S$. aureus (39.3\%) followed by Pseudomonas aeruginosa (20.67\%), E.coli (16.02\%), Proteusspp. (8\%) and Klebsiella spp. (6.67\%). The findings of present study are in closer conformity with some earlier studies which were performed in the same study pattern, reported $S$. aureus as the most widespread bacterial isolate of wound infection Mawalla et al. [19] and Mama et al. [20]. But these fi Jeol et al. [21] and Manikandan et al. [22] where Pseudomonas aeruginosa followed by $S$. aureus were commonest isolates.

The highest prevalence of $S$. aureus may be due to endogenous source of infection and from environmental contamination may also cause infection in addition to infection from surgical instruments. As $S$. aureus is normal flora of skin, with the disruption of this natural barrier it easily enters into wounds.
Antibiotic resistance to commonly prescribed antibiotics was high. This high level of resistance is alarming. The absolute resistance to ampicillin and amoxycillin/clavulanic acid (penicillin class) was not unpredicted as these antibiotic frequently implicated in self-medication in Gilgit- Baltitan. In Current studies Gram positive isolates showed the average resistance of $95.13 \%$ and $88.89 \%$ to ampicillin and amoxycillin/clavulanic acid (penicillin class) respectively and $86.11 \%$ resistance to erythromycin (macrolide class) these findings goes in line to study conducted in Ethiopia where Gram positive isolates showed 82-100\% resistance against three classes penicillin, tetracycline and Phenicole class Godebo et al. [23]. All the Grampositive isolates showed $100 \%$ sensitivity to linezolid this is in great agreement with the study conducted in Iran by Nazeer et al. [12] 
and Fatholahzed et al. [24] In contrast, study conducted in Bangladesh showed 94.3\% sensitivity against linezolid Sultana et al. [17] Significant susceptibility of Gram-positive isolates to linezolid and vancomycin, might be due to their low availability, cost and toxic effects Mama et al. [20] In present study Gram negative isolates show $100 \%$ of average sensitivity to imipenem followed by piperacillin-tazobactum $(96.5 \%)$ this is similar to the findings of Nazeer et al [12] reported $100 \%$ sensitivity to imipenem and $70-100 \%$ sensitivity to piperacillintazobactum. Almost similar findings were reported from a study conducted in Bangladesh by Sultana et al [17] who reported $93.54 \%$ sensitivity to imipenem.

The high frequency of resistance against multiple drugs is a reflection of inappropriate use of antibiotics, lack of laboratory diagnosis and unavailability of guidelines. This inappropriate prophylaxis of antibiotics and unskilled practitioners leads to emergence of resistance in bacteria. As a result, they have lost their efficacy in the treatment of wound infection Barker et al. [25].

\section{Conclusion}

S. aureus is the primary cause of infection in Gilgit- Baltistan area. The increasing multidrug resistance may be a reflection of inappropriate use of antibiotics, lack of laboratory diagnosis and unavailability of guidelines. Periodic monitoring of etiological agents and their susceptibility profile of pathogens from infected wounds help physicians to prescribe right drug and discourage emerging resistance.

\section{Authors' contributions}

Conceived and designed the experiments: $S$ Yaqub \& $\mathrm{K}$ Ahmed, Performed the experiments: S Yaqub, R Imran \& N Shuja, Analyzed the data: S Yaqub, SU Din \& MA Nafees, Contributed materials/ analysis/ tools: R Imran \& I Hussain, Wrote the paper: MA Nafees \& SU Din.

\section{References}

1. Pondai K, Fente G \& Oladapo O (2012). Current Microbial isolates from Wound Swabs, their culture and sensitivity patterns at Niger Delta university teaching hospital, Okolobri, Nigeria. Trop Med and Hlth 41(2): 49-53.

2. Prabha SP, Rani DM, Lakshmi K, Chitralekha S \& Illamani V (2015). Study of Bacteriological Etiology of Wound Infections. Res $J$ of Pharma Bio \& Chem Sci 6(2): 270-274.

3. Mangram AJ, Horan TC, Pearson Ml, Silver LC \& Jarvis WR (1999). Guideline for Prevention of Surgical Site Infection. Centers for Disease Control and Prevention (CDC) Hospital Infection Control Practices Advisory Committee. Am J Infect Control 27: 97-132.

4. Mulu A, Moges B, Tesema \& Kassu, A (2006). Patterns and multiple drug resistance of bacterial pathogens at university of Gondar teaching hospital, Northwest Ethiopia. Ethio Med J 44(2): 125-131.

5. Akingbade OA \& Balogun SA (2012). Plasmid Profile Analysis of Multidrug Resistant Pseudomonas aeruginosa isolated from wound infections in South West, Nigeria. Wld App Sci J 20 (6): 766775.

6. Micheal W (2011). Bacterial impact on wound healing from contamination to infection.Australian Wound Management Association Inc. (AWMA) version 1.5.

7. Davies J \& Davies D (2010). Origins and Evolution of Antibiotic Resistance. JASM Rev 74(3): 417-433.

8. Levine NS, Lindberg RB, Mason AD \& Pruitt BA (1976). The quantitative swab Culture and smear: a quick, simple method for determining the number of viable aerobic bacteria on open wounds. $J$ of Trauma 16: 89-94.

9. Bauer AW, Kirby WMM, Sherries JC \& Turck M (1966). Antibiotic Susceptibility testing by a standard single disc method. Am J clin. Pathol 45: 493-496. 
10. Ahmad K \& Imran (2008). Prevalence and antibiograms of uncomplicated lower urinary tract infection in human population of Gilgit, Northern Areas of Pakistan. . Pak J Zool 40: 295-301.

11. CLSI (2012). Performance Standard for Antimicrobial Disc Susceptibility Test, M 100-S22 -32(32).

12. Nazeer HA, Sheik MK \& Kolasani PB (2014). Aerobic bacteriology of wound infection with special reference to MRSA. $J$ Clin \& Exp Res 2(10): 54-55.

13. Egbe, CA, Omoregie R, Igbarumeh IO, Onemu S (2011). Microbiology of wound infections and associated risk factors among patients of a tertiary hospital in Benin City, Nigeria. J Res Hlth. Sci 11: 109-113.

14. Taiwo SS, Okesina AB \& Onile BA (2002). In-vitro antimicrobial susceptibility pattern of bacterial isolates from wound infection in University of Ilorin teaching hospital. Afr J Clin Exp Microbiol 3: 6-10.

15. Bhatt CP, Baidya R \& Karki P (2014). Multi Drug Resistance Bacterial Isolates of Surgical Site Infection. J Med Micro 4: 203-209.

16. Mulugeta KA \& Bayeh A (2011). Bacteriology and antibiograms of pathogens fromwound infections at Dessie Laboratory, North East Ethiopia. Tanz $J$ Health Res 13(4): 444-447.

17. Sultana S \& Mawla N (2015). Current Microbial Isolates from wound Swab and their susceptibility pattern in Private Medical College Hospital in Dhaka city. Delta Med Col J 3(1): 25-30.

18. Kehinde, AO, Ademola SA, Okesola AO, Oluwatosin OM \& Bakare RA (2004). Pattern of bacterial pathogens in burn wound infection in Ibadan, Nigeria. Annals of Burn n Fire Disasters XVII (1): 12-15.
19. Mawalla B, Mshana SE, Chalya PL, Imirzalioglu C \& Mahalu W (2011). Predictors of Surgical site infections among patients undergoing major surgery at Bugando Medical Centre in Northwestern Tanzania. BMC Surgery 11: 11-21.

20. Mama M, Adissa A \& Sewunet T (2014). Antimicrobial Susceptibility Pattern of Bacterial Isolates from Wound Infection and Their Sensitivity to Alternative Topical Agents at Jimma University Specialized Hospital, South-West Ethiopia. Annls of Clin Microbiol and Antimicrobial 13: 14.

21. Jeol MD (2012). Bacteriological spectrum of post-operative wound infections and their antibiogram in a tertiary hospital, Dar es salaam, Tanzania. Dissertation at Muhimbilli University of Health and Applied Sciences.

22. Manikandan C \& Amsath A (2013). Antibiotic susceptibility of bacterial strains isolated from wound infection patients in Pattukkottai, Tamilnadu, India. Int J Curr Microbiol App Sci 2(6): 195203.

23. Godebo G, Gebre K \& Himanot T (2013). Multidrug-resistant bacterial isolates in infected wounds at Jimma University Specialized Hospital, Ethiopia Ann of Clin Microbiol and Antimicrob 12: 17.

24. Fatholahzadeh B, Emaneini M, Gilbert G, Udo E, Aligholi M \& Modarressi $\mathrm{MH}$ (2008). Staphylococcal cassette (chromosome mecSCCmec) analysis and antimicrobial susceptibility patterns of methicillin-resistant Staphylococcus aureus (MRSA) isolates in Tehran, Iran. $J$ of Microb and Drug Resis 14(2): 17-2.

25. Barker KF 1999. Antibiotic Resistance: A Current Perspective. Br J Clin Pharmacol 48: 109-124. 